\title{
INTERLEUKIN-1B AND CYCLOOXYGENASE-2 PROINFLAMMATION ANALYSIS AND IN SILICO DOCKING NUCLEAR FACTOR KAPPA B ON ENDOMETRIOSIS CELL CULTURE GIVEN HEPTYL GALLATE AND OCTYL GALLATE TREATMENT
}

\author{
ARLENI BUSTAMI ${ }^{1 *}$, FAJAR SULISTYA UTAMI ${ }^{2}$, RAHMI BUDIARTI², HERI WIBOWO ${ }^{1,3}$ \\ ${ }^{1}$ Integrated Laboratory, Faculty of Medicine, Universitas Indonesia, Jakarta, Indonesia. ${ }^{2}$ Magister Program in Biomedical Sciences, Faculty \\ of Medicine, Universitas Indonesia, Jakarta, Indonesia. ${ }^{3}$ Department of Parasitology, Faculty of Medicine, Universitas Indonesia, Jakarta, \\ Indonesia. Email: arleni.ab@gmail.com \\ Received: 24 October 2018, Revised and Accepted: 11 January 2019
}

\section{ABSTRACT}

Objective: The aim of this study is to analyze the effect of octyl gallate and heptyl gallate toward the regulation of interleukin- $1 \beta$ and cyclooxygenase (COX)-2 proinflammatory factor on endometriosis cell culture and analyze its activity toward nuclear factor kappa B (NFkB) target protein through in silico docking technique.

Methods: In vitro study was performed on endometriosis cells cultured treated with two dosages each of heptyl and octyl gallate $(51.2 \mu \mathrm{g} / \mathrm{mL}$ and $102.4 \mu \mathrm{g} / \mathrm{mL}$ ) for $48 \mathrm{~h}$, then followed by $10 \mathrm{ng} / \mathrm{mL}$ lipopolysaccharides (LPS) induction for $24 \mathrm{~h}$. The positive control group was treated by LPS induced and the negative control was treated without LPS. Inflammation regulation was evaluated with enzyme-linked immunosorbent assay technique and in silico docking analyzed using bioinformatics technique.

Results: Molecular docking analysis with gallic acid and their derivatives showed that more stable affinity and stronger binding found on octyl gallate than heptyl gallate and gallic acid at the active site of NFkB.

Conclusions: Based on this study results, octyl gallate and heptyl gallate were proven to be able to reduce COX-2 proinflammatory factor through NFkB pathway as an inflammatory regulator; thus, it has the potential to be developed as a therapy for endometriosis.

Keywords: Heptyl gallate, Octyl gallate, Endometriosis, In silico docking nuclear factor kappa B, Cyclooxygenase-2, Interleukin-1 $\beta$

(C) 2019 The Authors. Published by Innovare Academic Sciences Pvt Ltd. This is an open access article under the CC BY license (http://creativecommons. org/licenses/by/4. 0/) DOI: http://dx.doi.org/10.22159/ajpcr.2019.v12i2.30399

\section{INTRODUCTION}

Endometriosis is a pathological disease caused by the uncontrolled proliferation of ectopic tissue outside the endometrial cavity [1]. Giudice (2010) defines endometriosis as an inflammatory condition characterized by tissue lesions such as endometrium outside the uterus and generally associated by pelvic pain and infertility [2]. The endometriosis lesions growth could trigger the concentration of proinflammatory cytokines in the peritoneal cavity leading to chronic inflammation [3]. Proinflammatory factors such as interleukin (IL)-1 $\beta$ and tumor necrosis factor (TNF) $-\alpha$ activate the nuclear factor-kappa B (NF-kB) signaling pathway and hypoxia-inducible factor $-1 \alpha$, thus increasing the expression of cyclooxygenase (COX)-2 in endometriosis. $\mathrm{NF}-\mathrm{kB}$ is suggested in mediating the occurrence of inflammation thereby increasing the secretion of several cytokines, including TNF- $\alpha$, IL 1, IL 6, IL8, IL 10, interferon gamma, macrophage inflammatory proteins 1-2, RANTES, intercellular adhesion molecule-1, matrix metallopeptidase-9, and COX-2 which also influence the proliferation excess, invasion, angiogenesis, and persistence of ectopic endometriosis growth [4-6].

IL- $1 \beta$ is a proinflammatory cytokine that stimulates endometriosis cells producing cytokines and growth factors which have a role in adhesion, growth, invasion, inflammation, and angiogenesis in endometriosis $[7,8]$. Previous studies showed that IL-1 $\beta$ induced the expression of vascular endothelial growth factor (VEGF) and COX-2, angiogenic factors, in some cancers. As already known, COX-2 and VEGF play an important role in the angiogenesis process in endometriosis $[9,10]$.

At present, the management of endometriosis focused on hormonal therapy and conservative surgery, resulting in approximately 50\% of women with endometriosis reduced pain [11], and the recurrence rate after endometriosis is around $11-32 \%$ within $1-5$ years [12]. Therefore, it is suggested to develop an advanced and effective method as promising management of endometriosis.

Derivatives of alkyl ester from gallic acids such as heptyl gallate and octyl gallate have the ability to suppress the proliferation and induce apoptosis in some cancer cells [12]. The novelty of this study was to analyze the effects of alkyl gallate derivatives, namely heptyl gallate and octyl gallate as anti-inflammatory candidates in endometriosis cells. The effectiveness of gallic acid is influenced by the ability of entering into the cell and affecting the biological activity of the cell. Gallic acid has hydrophobic properties, influenced by the length of the alkyl group carbon chain, which supports the penetration into the cell. The difference in gallic acid and alkyl ester gallate derivatives lies in the number of carbon atoms bound to the side chain, thus giving physicochemical characteristics, especially lipophilicity, which can be seen from the partition coefficient (C log P) [13]. Heptyl gallate and octyl gallate are modifications of gallic acid by adding carbon chains to the alkyl group of the tool so that it is more hydrophobic. The addition of $\mathrm{OH}$ groups to the groups of gallic acid derivatives (heptyl gallate and octyl gallate) increases the solubility and hydrophobicity of the substance so as to facilitate the penetration and increase of the biological activity of the natural substances within the cell. Lipophilic chain length on the side chain alkyl ester form affects the affinity and cell membrane permeability to these substances $[14,15]$. Our previous research proved that octyl gallate suppressed the expression of nuclear factor-kappa B (NF-kB) mRNA, proinflammatory pathway transcription factor, and the proliferation of endometriosis cell in vitro [16]. Therefore, it is necessary to prove the mechanism through bioinformatics analysis 
with in silico docking techniques to obtain compounds which more potential, stable, and has specific activities in inhibiting NFkB $[17,18]$.

The purpose of this study was to identify the bond strength and potential inhibition of gallic acid derivatives, heptyl gallate, and octyl gallate, toward the protein target, NF- $\mathrm{BB}$ through in silico docking technique and the effect toward the regulation of proinflammatory cytokines, IL-1 $\beta$ and COX-2, in primary cultures of endometriosis cells.

\section{MATERIALS AND METHODS}

\section{Materials}

Gallic acid was synthesized by the Chemical Department FKUI, fetal bovine serum (FBS), Fungizone, powder Dulbecco's modified eagle's medium F-12 (DMEM F-12) from Gibco/Life Tech USA, penicillin/ streptomycin (Sigma-Aldrich), phosphate buffered saline (Merck. IL1ß), and COX-2 ELISA Kit (Quantikine R and D and MyBioSource).

\section{In silico docking analysis}

In silico docking, the study was performed to analyze docking energy values $(\Delta G)$ and amino acids association in the process of interaction between macro NFkB molecules and ligands (octyl gallate and heptyl gallate) using software Marvin Sketch, AutoDock, PyMOL, and LigPlus which are designed for docking.

\section{Isolation and primary culture of endometriosis tissue}

The endometriosis tissues patients' were obtained using laparoscopy procedure, they were put in the transport medium (DMEM F-12 containing $2 \%$ penicillin/streptomycin and $2 \%$ Fungizone). Then endometriosis cells are obtained by isolating enzymatically cells using Type IV collagenase and culturing it until the cells reached $6 \times 10^{6}$ in complete medium (DMEM F-12 containing 1\% penicillin/streptomycin, $1 \%$ Fungizone, and $20 \%$ FBS). The $2.5 \times 10^{4}$ cells/well were grown in 12 well plates, then treated with heptyl and octyl gallate with two doses (51.2 $\mu \mathrm{g} / \mathrm{mL}$ and $102.4 \mu \mathrm{g} / \mathrm{mL}$ ) for $48 \mathrm{~h}$, followed by induction of $10 \mathrm{ng} / \mathrm{mL}$ lipopolysaccharides (LPS) for $24 \mathrm{~h}$. The positive control group only induced by LPS, and negative control was treated without LPS.

\section{Analysis of levels of cytokines IL-1 $\beta$ and COX-2}

Inflammatory regulation was assessed from the level of cytokines IL$1 \beta$ and COX-2 with ELISA (Quantikine, R and D system, MyBioSource) techniques. Analysis of level IL-1 $\beta$ performed with add $200 \mu \mathrm{L}$ of standard, sample, and control to each well, then incubated for $2 \mathrm{~h}$ at lid temperature with adhesive cover strips. After $1 \mathrm{~h}$, repeat the steps for washing, followed by adding $200 \mu \mathrm{L}$ of substrate solution to each well,

Table 1: Results of in silico docking between ligands and NFkB

\begin{tabular}{llllc}
\hline No & Compound & $\begin{array}{l}\text { Binding energy } \\
\text { score (kkal/mol) }\end{array}$ & pKi $(\boldsymbol{\mu M})$ & HB \\
\hline 1 & Gallic acid & -7.66 & 2.42 & 5 \\
2 & Heptyl gallate & -7.68 & 2.37 & 2 \\
3 & Oktyl gallate & -7.98 & 1.41 & 3 \\
\hline NFkB: Nuclear factor kappa B & pKi: Inhibition constant, HB: Hydrogen bonds
\end{tabular}

cover with aluminum foil and incubate for $20 \mathrm{~min}$ at room temperature. Then, add $50 \mu \mathrm{L}$ of stop solution to each well, then the color changes from blue to yellow, then read the OD of each well with a spectrophotometer within $30 \mathrm{~min}$ at a wavelength of $450 \mathrm{~nm}$ and correction at 540 or $570 \mathrm{~nm}$. Analysis of level COX-2 performed with add $100 \mu \mathrm{l}$ standard, sample, and control to each well, then incubated for $90 \mathrm{~min}$ at $37^{\circ} \mathrm{C}$ cover with adhesive cover strips, biotinylated COX-2 antibodies prepared $30 \mathrm{~min}$ before incubation is complete, after incubation do aspiration and washing by adding $200 \mu \mathrm{L}$ wash buffer, repeat up to 3 times washing. At the end of each wash, dry it by placing the inverted plate on the tissue. Put $100 \mu \mathrm{L}$ of biotinylated COX-2 antibody on each well, cover it with the adhesive cover strip by incubating for $60 \mathrm{~min}$ at $37^{\circ} \mathrm{C}$, before incubation is finished $30 \mathrm{~min}$ before preparing enzymeconjugate. After incubation, complete aspiration and washing by adding $200 \mu \mathrm{L}$ of wash buffer, repeating up to 4 times of washing. At the end of each wash, dry it by placing the inverted plate on the tissue. Then, add $100 \mu \mathrm{L}$ of enzyme-conjugate to each well, cover with the adhesive cover strip and incubate for $30 \mathrm{~min}$ at $37^{\circ} \mathrm{C}$, re-aspirate and wash with $200 \mu \mathrm{L}$ of wash buffer, repeat up to 6 times of washing. At the end of each wash, dry it by placing the inverted plate on the tissue, then add $100 \mu \mathrm{L}$ of Color Reagent A to each well, incubate at $37^{\circ} \mathrm{C}$ until the color turns dark in $30 \mathrm{~min}$, add $100 \mu \mathrm{L}$ of Color Reagent $\mathrm{C}$ to each well, step finally, read the OD of each well with a spectrophotometer within $10 \mathrm{~min}$ at a wavelength of $450 \mathrm{~nm}$ and correction at 540 or $570 \mathrm{~nm}$.

\section{RESULTS}

Based on the results of in silico docking analysis, the docking energy (binding energy score $/ \Delta G$ ) of gallic acid compounds, heptyl gallate and octyl gallate as ligand against protein $\mathrm{NFkB}$ targets respectively $-7.66 \mathrm{kkal} / \mathrm{mol},-7.68 \mathrm{kkal} / \mathrm{mol}$ and $-7.98 \mathrm{kkal} / \mathrm{mol}$. $\Delta \mathrm{G}$ shows the strength of the ligand affinity with the target protein in which the higher of the negative $\Delta \mathrm{G}$ value the interaction and conformation between ligand and protein will be more constant and stable [19]. In this study, the octyl gallate showed a stronger and more stable affinity toward NFKB than heptyl gallate and gallic acid.

The amino acids through hydrogen bonds (HB), Tyr285, Lys221, Ser222, Ser226, Ser220, Pro223, and Lys252, performed the bond between ligands with NFkB residues at a distance of $<3,31 \AA$ (Fig. 1). HB which could increase the ligand activity was found in the amino acid residues Ala225. The octyl gallate had 3 HB with amino acids Lys221, Ser2260, and Ala225, while heptyl had two amino acids, Ser226 and Lys283. The quantity of HB made ligand interactions between NFkB proteins and compounds heptyl gallate and octyl gallate became stronger. Thus, the octyl gallate showed more potent for interaction and inhibitory activity toward NFKB than the heptyl gallate. Another docking indicator is the value of the inhibition constant (pKi), which showed the inhibitor value between the ligand-protein complexes. A low pKi value is a good indicator for the formation of a ligand-protein complex. The result of $\Delta \mathrm{G}, \mathrm{pKi}$, and $\mathrm{HB}$ is presented in Table 1 .

The effect of heptyl gallate and octyl gallate on primary endometriosis cells toward pro-inflammatory cytokines IL-1 $\beta$ in this study showed

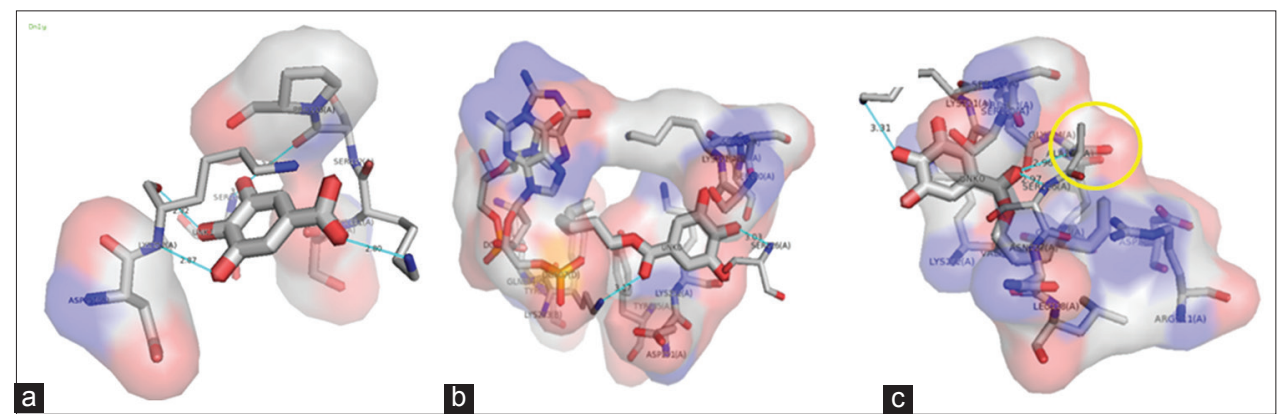

Fig. 1: Visualization of nuclear factor kappa residual interactions with compounds (a) Gallic acid, (b) Heptyl gallate, (c) Octyl gallate 


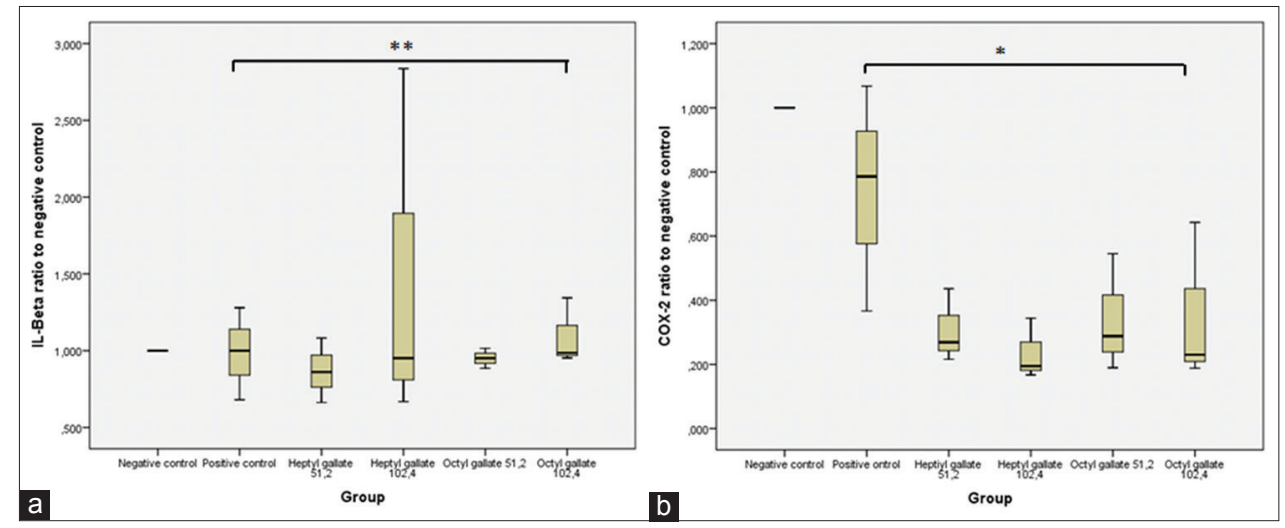

Fig. 2: The production ratio of (a) interleukin-1 $\beta$ level ${ }^{*} \mathrm{p}>0.05=$ no significant difference compared to the group in endometriosis cells given heptyl gallate and octyl gallate compared with positive controls and (b) cyclooxygenase-2level * $<0.05=$ significantly different compared to endometriosis cells given heptyl gallate and octyl gallate compared with positive controls. Describe HG: Heptyl gallate, OG: Octyl gallate, Dosage: $51.2 \mu \mathrm{g} / \mathrm{mL}$ and $102.4 \mu \mathrm{g} / \mathrm{mL} . \mathrm{n}=3$

that both compounds had the potential to suppress IL-1ß generation, but there was no significant difference between the two compounds $(p>0.05)$. On the other hand, there were significant differences in inhibition of COX-2 production in both heptyl and octyl gallate $(\mathrm{p}=0.03)$, although the difference in dosage was not affect the strength of the production effect (Fig. 2).

\section{DISCUSSION}

In silico docking analysis between gallic acid, heptyl gallate, and octyl gallate as ligands with NFkB target proteins regarding the affinity, showed that octyl gallate was stronger and more stable in affinity compared to heptyl gallate and gallic acids, thus octyl gallate was suggested more potential in inhibiting the NFKB pathway than heptyl gallate and gallate acid. This was in line with the results of our previous study that octyl gallate more suppressed the relative expression of $\mathrm{NFKB}$ mRNA in endometriosis cells using quantitative real-time polymerase chain reaction identification compared to heptyl gallate and gallic acid $[16,18,20]$. The results of the study using in silico docking of gallic acid derivative compounds on the dihydrofolate reductase malarial receptor showed that octyl gallate had strong interactions and had the greatest inhibitory activity [21].

The suppression of NFKB expression is caused by several factors, one of which is suppressed by proinflammatory cytokines IL-1 $\beta$. Although in this study IL- $1 \beta$ production was not statistically significantly decreased, both heptyl and octyl gallate had the potential to suppress $\mathrm{NFkB}$ expression. Another possibility that causes NFkB inhibition is still poorly understood, and further research is needed.

Studies on the treatment of DLBS2411 can increase IKK $\alpha$ phosphorylation and activate NF-kB, where high levels of NFkB can increase the expression of COX-2 and prostaglandin E2 [22]. The remarkable thing from this study was that the inhibited effect on NFkB mRNA expression also suppressed the COX-2 production. Previous research reported that COX-2 and VEGF had an important role in angiogenesis in endometriosis $[9,10]$ and high COX-2 production also played a role in increasing pain in patients [23]. With the ability of octyl gallate and heptyl gallate which can affect the mechanism of proinflammatory regulation by suppressing the NFkB pathway and COX-2 secretion, the inflammatory process could be prevented and or suppressed, so the process of proliferation, invasion, angiogenesis, and persistence of ectopic implants in endometriosis cells was not occurred. This was in line with the results of our previous studies that demonstrated the ability of gallate acid, heptyl gallate, and octyl gallate to reduce cell proliferation and increase apoptotic endometriosis cells $[24,25]$. Likewise, previous studies reported that the alkyl ester derivatives of gallic acid such as heptyl gallate and octyl gallate had the ability to suppress proliferation and induced apoptosis in some cancer cells [12].

\section{CONCLUSIONS}

In the silico docking study showed octyl gallate had a stronger binding and more stable affinity in inhibiting NFkB protein because it had the highest docking energy $(\Delta G)$, the lowest pKi, and the highest number of HB compared to heptyl gallate and gallic acid. In addition, we proved that octyl gallate and heptyl gallate have the potential to suppress IL$1 \beta$ secretion driving to NFKB mRNA expression and COX-2 decrease in endometriosis cells. Octyl gallate and heptyl gallate can be developed as promising agents in the management of endometriosis through their inhibitory effects in the proinflammatory pathway. In vivo study is still needed to prove the effects of these two compounds as endometriosis management.

\section{ACKNOWLEDGMENTS}

The funding of this research was supported by PUPT 2017 grant. The authors are thankful to Dr. R. Muharam, SpOG (K) for providing the necessary samples for this research and also to Dr. Ade Arsianti for preparing octyl gallate and heptyl gallate.

\section{AUTHORS' CONTRIBUTIONS}

Dr. Arleni has the role of supervising research and directing the making of manuscripts; Mrs. Fajar Sulistya Utami performed the experiment and wrote the manuscript; Dr. Heri helped in supervising data processing analysis, and Mrs. Rahmi Budiarti performed endometriosis cells isolation and culture.

\section{CONFLICTS OF INTEREST}

We declare there are no conflicts of interest in this research.

\section{REFERENCES}

1. Hidetaka HR. Pathological Aspect and Pathogenesis of Endometriosis. In: Harada T, editor. Endometriosis Pathogenesis and Treatment. Japan: Springer; 2014. p. 9-18.

2. Johnson NP, Hummelshoj L. World endometriosis society montpellier C. Consensus on current management of endometriosis. Hum Reprod 2013;28:1552-68.

3. Halis G, Arici A. Endometriosis and inflammation in infertility. Ann N Y Acad Sci 2004;1034:300-15.

4. Burney RO, Giudice LC. Pathogenesis and pathophysiology of endometriosis. Fertil Steril 2012;98:511-9.

5. Wu MH, Hsiao KY, Tsai SJ. Endometriosis and possible inflammation markers. Gynecol Minim Invasive Ther 2015;4:61-7.

6. McKinnon BD, Bertschi D, Bersinger NA, Mueller MD. Inflammation 
and nerve fiber interaction in endometriotic pain. Trends Endocrinol Metab 2015;26:1-0.

7. Rinata E, Noorhamdani S. Pemberian genistein pada kultur sel endometriosis dalam menurunkan kadar interleukin-1 $\beta$. Obstet Ginekol 2014;22:39-45

8. Ahmad SF, Rakhila H, Akoum A. Macrophages in pathophysiology of endometriosis. In: Harada T, editor. Endometriosis Pathogenesis and Treatment. Canada: Springer; 2014. p. 61-85.

9. Huang F, Cao J, Liu Q, Zou Y, Li H, Yin T, et al. MAPK/ERK signal pathway involved expression of COX-2 and VEGF by IL-1 $\beta$ induced in human endometriosis stromal cells in vitro. Int J Clin Exp Pathol 2013;6:2129-36

10. Tao X, Xie Y, Wang L, Gu W, Yu X, Zhou X, et al. The expression of $\operatorname{cox}-2, N F-\kappa B$, and VEGF in ectopic endometrial tissues within fallopian tubes suggests different etiologies. Int $\mathrm{J}$ Gynecol Pathol 2014;33:411-7.

11. Wu Y, Guo SW. Suppression of IL-1beta-induced COX-2 expression by trichostatin A (TSA) in human endometrial stromal cells. Eur J Obstet Gynecol Reprod Biol 2007;135:88-93.

12. Choubey S, Varughese LR, Kumar V, Beniwal V. Medicinal importance of gallic acid and its ester derivatives: A patent review. Pharm Pat Anal 2015;4:305-15.

13. Locatelli C, Filippin-Monteiro FB, Creczynski-Pasa TB. Alkyl esters of gallic acid as anticancer agents: A review. Eur J Med Chem 2013;60:233-9.

14. Feng Q, Kumagai T, Nakamura Y, Uchida K, Osawa T. Correlation of antimutagenic activity and suppression of CYP1A with the lipophilicity of alkyl gallates and other phenolic compounds. Mutat Res 2003;537:101-8.

15. Tammela P, Laitinen L, Galkin A, Wennberg T, Heczko R, Vuorela H, et al. Permeability characteristics and membrane affinity of flavonoids and alkyl gallates in caco-2 cells and in phospholipid vesicles. Arch Biochem Biophys 2004;425:193-9.

16. Bustami PS, Muharam R, Wibowo H. Effects of gallic acid and its derivates on inflammatory regulation of endometriotic primary cultures study on NFkB mRNA expression and IL6 secretion. Biomed Pharm J 2018;11:3.

17. Syahputra AL, Sumaryada T. Simulasi docking kurkumin enol, bisdementoksikurkumin dan analognya sebagai inhibitor enzim12-lipoksigenase. J Biofis 2014;10:55-67.

18. Ranganatha SS, Govindappa M, Ramachandra YL. In silico studies of $\mathrm{NF}-\mathrm{\kappa B}$ protein as anti-cancer and anti-inflammatory target. J Comp Method Mol Design 2013;3:26-33.

19. Ulfa DM, Arsianti A, Radji M. In silico docking studies of gallic acid structural analogues as Bcl-Xl inhibitor in cancer. Asian J Pharm Clin Res 2017;10:119.

20. Faried A, Kurnia D, Faried LS, Usman N, Miyazaki T, Kato H, et al. Anticancer effects of gallic acid isolated from indonesian herbal medicine, phaleria macrocarpa (Scheff.) boerl, on human cancer cell lines. Int J Oncol 2007;30:605-13.

21. Arsianti AA, Astuty H, Fadilah F, Bahtiar A, Tanimoto H, Kakiuchi K. Design and screening of gallic acid derivatives as inhibitors of malarial dihydrofolate reductase (Dhfr) by in silico docking. Asian J Pharm Clin Res 2017;10:330.

22. Wulandari OM, Tjandrawinata RR. Bioctive fraction DLBS2411 from Cinnamomum burmannii, (Nees and T.Nees) Blume as colon and gastroprotector by stimulating MUC5AC and cyclooxygenase-2 gene expression. Int J Pharm Pharm Sci 2016;8:202-7.

23. Budi PG, Sumapraja K, Natadisastra M, Harzief HS, Pratama G, Hestiantoro A. Penggunaan DLBS1442 untuk terapi medikamentosa terkini pada penderita endometriosis. Medicinus 2013;26:4-7.

24. Bustami SS, Sopiah PP, Zoya MA, Ade A, Natadisastra RM. Cell viability inhibition effect of gallic acid and its synthetic derivative forms on primary cultured endometriosis cells. Adv Sci Lett 2017;23:6681-3.

25. Bustami HD, Adyasa ZM, Nareswari SS, Sopiah P, Arsianti A, Natadisastra RM. The apoptotic effect of gallic acid and its derivatives on primary cultured endometriosis cells. Adv Sci Lett 2017;23:6695-8. 